\title{
Effectuation Approach in Accessing Entrepreneurial Education Significance on Students' Entrepreneurial Intention
}

\author{
Ayotunde Adetola Adelaja ${ }^{*}$, Modile Adekunle Umar ${ }^{2}$, Mike Terkuma Soomiyol ${ }^{3}$, \\ Roshidah Ahmad ${ }^{3}$, Iliyasu Shiyanbade Najeemdeen ${ }^{4}$, Bello Taofik Abidemi ${ }^{3}$ \\ 1 School of Business Management, Universiti Utara Malaysia, Malaysia \\ 2 Universiti Malaysia Perlis, Malaysia \\ ${ }^{3}$ Othman Yeop Abdullah Graduate School of Business, Universiti Utara Malaysia, Malaysia \\ ${ }^{4}$ Universiti Sultan Zainal Abidin, Malaysia
}

\begin{abstract}
Using the Sarasvathy's effectuation theory (2001), this study assesses the practical significance of entrepreneurial education in enhancing students' entrepreneurial intention of examining the students' perceived significance of access to finance as a determining factor to entrepreneurship as well as the moderating effect of financial access on the relationship between entrepreneurial education and entrepreneurial intention. To achieve the study objectives, an online survey via google form was sent out to UUM students who have at one time has entrepreneurial education exposure. The study respondents include international and local levels of both postgraduate and undergraduate students. 250 students completed the online survey within one month. The data collected were analysed using IBM SPSS version 23 with pre-installed process macro developed by Hayes (2013). The findings reveal that both entrepreneurial education and access to finance contributes significantly to their entrepreneurial intention. However, the students perceive access to finance as a causal factor to entrepreneurial intention rather than an effectuation factor. Hence, the education offered can be argued to have more of managerial implications rather than entrepreneurial implications.
\end{abstract}

Keywords: Entrepreneurial Intention, Entrepreneurial Education, Access to Finance, Effectuation Theory

JEL Classification: L26

Paper Type: Research

*Corresponding author: E-mail: ayoadelaja@live.com 


\section{INTRODUCTION}

Entrepreneurial activities had been argued to create a destructive chain by eliminating the traditional ways of producing goods and services. Through entrepreneurship, innovative ideas are encouraged. In this process, national gross domestic product (GDP) are boosted (Maina, 2014; Kayed, 2006). However, there are popular beliefs that the execution of the entrepreneur ideas or opportunity solely depend on resource availability (OECD, 2002; OECD, 2013a). Entrepreneurial resources influencing entrepreneurial intention are not limited to, access to finance, infrastructure, role model and entrepreneurial education (Khan \& Anuar, 2018; Adelaja \& Arshad, 2016; Bosma, Hessels, Schutjens, Van Praag \& Verheul, 2012; Minniti, 2008; Scherer, Adams, Carley \& Wiebe, 1989).

In this study, attention is geared towards two factors which earlier scholars argued to influence entrepreneurial intention among students to establish firms mostly being referred to as SMEs. These are entrepreneurial education and access to finance. The logic behind choosing these two factors lies in the notion that entrepreneurial education among youths in today's world has gained wider attention (Neck \& Greene, 2011; Kuratko, 2005). In addition, several studies argued that entrepreneurial education teaches students on how to turn the limited available resources into valuable commodities by instilling in them entrepreneurial spirit, cognition and skills needed (Baruch, 2009; Paul \& Moser, 2009).

Meanwhile, some studies argued that there is a disconnection between entrepreneurial education, knowledge and the needed entrepreneurial knowledge, skills and spirit needed to become entrepreneurs in the society (Olorundare \& Kayode, 2014). More so, these youths were regarded as risk takers, thus indirectly dubbed entrepreneurs provided they have the resources (Kirby, 2004). Since entrepreneurship is about risktaking abilities, it is expected that youths in recent times are entrepreneurs. On the opposite side, studies such as (Driga, Lafuente \& Vaillant, 2009; Praag \& Ophem, 1995) reveals that these youths are less willing to become entrepreneurs.

Attention is as well given to the perceived influence of access to finance on entrepreneurial intention among nascent entrepreneurs that is, students. The logic behind examining access to finance on students' entrepreneurial intention lies in the perception that although there are numerous studies on this concept, the majority of them gave excellent attention to SMEs (Adeyele, 2018; Khan \& Anuar, 2018) leaving the perception of students especially higher education institution students unattended.

Scholarly investigations on access to finance made it clear that finance is among the essential resources for business startups making it one of the discussed headlines in the field. As such, the absence of it or difficulty in accessing might hinder the transformations of ideas into reality (Adeyele, 2018; Khan \& Anuar, 2018; Mc Namara, Murro \& O'Donohoe, 2018; Rupeika-Apoga, 2014). From the ongoing discussion, it can be argued that entrepreneurial activities, engagement or involvement by nascent entrepreneurs rely heavily on financial availability (Khan \& Anuar, 2018; Kerr \& Nanda, 2009). To counter this ongoing issue, the government be it federal and states recognise the issues faced by entrepreneurs, and they are taking steps in mitigating this issue. For example, Khan and Anuar (2018) conclude that for entrepreneurial firms to remain competitive in Malaysia, the Malaysian government through several agencies had developed financial infrastructure and networks capable of meeting diverse entrepreneurial needs and support their competitiveness and growth. So also, from scholarly view Bhaumik, Fraser and Wright (2015) suggest scholars understand the relationship between the informal source of finance for the entrepreneurial firm.

Contrary to the perceived hindrance of access to finance as a threat to entrepreneurial intention, Mäkimurto-Koivumaa and Puhakka (2013) and Read and Sarasvathy (2005) argued that the purpose of entrepreneurial education is not really to teach the students 
how to source for the scarce resources, but to encourage them to adopt an adaptive approach towards entrepreneurship. That is, using the available scarce resources to fulfil their unlimited wants. Further arguments from the scholars categorise the available entrepreneurial education as managers' education and not entrepreneurship per se. This is because access to finance is recognised as a causal factor rather than effectual means of navigating through the dark future where entrepreneurs took the risk of losing what he can afford in the advent of loss situation during the entrepreneurial process.

Conferring the link between entrepreneurial and access to finance as a causal entrepreneurial factor rather than an effectual approach in enhancing entrepreneurial intention among students, this study objective is therefore to investigate the significance of entrepreneurial education and the moderating effect of access to finance in enhancing students' entrepreneurial intention using a casual and effectuation approach.

\section{LITERATURE REVIEW}

\subsection{Entrepreneurial Education and Entrepreneurial Intention}

The primary objective behind the adoption of entrepreneurial education is to create entrepreneurial awareness, equipped the students with the needed entrepreneurial skills, knowledge, cognition and entrepreneurial spirit (Arasti, Falavarjani \& Imanipour, 2012; Izedonmi, 2010) which enhance their entrepreneurial intention so that upon graduation, they need not be job hunters but, join the league of job creators (Baruch, 2009; Ahmad, Baharun \& Rahman, 2004). Given these, scholars opined the high rate of unemployment among youths which majority were fresh graduate could be mitigated (Garba, 2010; Paul \& Moser, 2009).

The empirical investigation by Efrata, Hadiwidjojo and Aisjah (2016) notes that exposing Indonesian students to entrepreneurial education dampens their intention towards entrepreneurship activities. In a similar study Adelaja and Minai (2018) examining the effectiveness of entrepreneurial education on Nigerian students using a pretestposttest approach argues that entrepreneurial education has an adverse effect on students' entrepreneurial intention.

On the contrary, Puni, Anlesinya and Korsorku (2018) argue a significant positive influence of entrepreneurial education exposure on students' entrepreneurial intention. Comparing entrepreneurial intention among students who were exposed to entrepreneurial education and those who did not register for entrepreneurial education, Mbuya and Schachtebeck (2016) conclude, irrespective of the course the student registered, they believed entrepreneurial education to influence their intention. Furthermore, the authors argued entrepreneurship students exhibit high personal attributes towards entrepreneurship. To support these argument Adelaja and Arshad (2016) compared the influencing factors of entrepreneurial intention between public and private higher education institutions in Malaysia. It was observed that entrepreneurial education was found to positively and significantly influence entrepreneurial intention between both samples. Although, Efrata, Hadiwidjojo and Aisjah (2016) argue the negative effect of entrepreneurial education in influencing students' entrepreneurial intention through the mediating effect of perceived feasibility. With this, this study proposes as follows:

$\mathrm{H}_{1}$ : Entrepreneurial Education has a significant influence on students' entrepreneurial intention 


\subsection{Reviews on Access to Finance}

Access to finance has been a source of arguments among entrepreneurial scholars, although most of the scholars argue that without access to finance, entrepreneurship is a 'no-go' area (Adeyele, 2018; Khan \& Anuar, 2018; Mc Namara, Murro \& O'Donohoe, 2018; Lee, Sameen \& Cowling, 2015; Rupeika-Apoga, 2014). Meanwhile, scholars such as Fowowe (2017) and Kim, Aldrich and Keister (2006) argue that access to finance might be an essential factor for a business-oriented person but not entrepreneurs. This is because entrepreneurs should have the ability to mitigate what they want with what they have (Mäkimurto-Koivumaa, \& Puhakka, 2013; Read \& Sarasvathy, 2005).

The significant influence of access to finance in entrepreneurship is not only limited to theoretical innovation in entrepreneurship but the practice as well. For example, the study of Lee, Sameen, and Cowling (2015) examined how the financial crises affect SMEs innovativeness in the UK. The scholars found that worsening conditions of financial leading to restriction of finance to innovative firms cause less innovative output.

In another study, Fowowe (2017) examined subjective and objective measures of the effects of financial access on 10,888 firms in 30 African states. The findings from this author argued access to finance as casual and effectual in nature. From a subjective view, the author concludes that access to finance has a significant negative effect on SMEs growth. Meanwhile, concerning the objective view, no negative effect was found. According to the study by Kim, Aldrich \& Keister (2006), access to finance should not be a barrier to the entrepreneurial industry if such an individual is entrepreneurial oriented.

Summarising the studies of Adeyele (2018), Khan and Anuar (2018), Mc Namara, Murro and O'Donohoe (2018) and Rupeika-Apoga (2014), access to finance can be viewed as an entrepreneurial influencing factor that can accelerate the students' entrepreneurial intention. These authors agreed that the availability of finance contributes significantly to students' entrepreneurial' intention. Meanwhile, the perceived nonavailability of finance access might jeopardise their intention towards entrepreneurship. It is logically presumed that without financial access it will be a difficult task for an entrepreneurial firm to kick off. Considering this phenomenon, the study proposes thus:

$\mathrm{H}_{2}$ : Access to finance is a significant factor that influences students' entrepreneurial intention

$\mathrm{H}_{3}$ : Access to finance has a significant moderating effect on the relationship between entrepreneurial education and entrepreneurial intention.

\subsection{Theoretical Framework}

Granting the preceding discussion about the influence of entrepreneurial education and the direct and the moderating relationship of access to finance, the conceptual framework is illustrated in Figure 1.

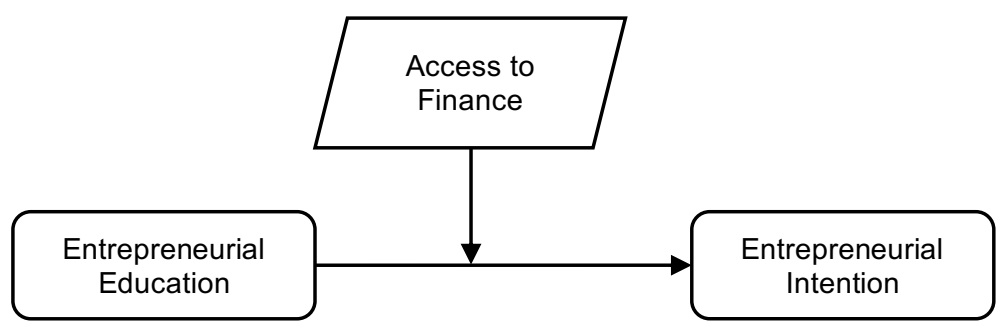

Figure 1. Conceptual Research Framework 


\subsection{Effectuation Theory}

Effectuation theory is concerned with a logical evaluation of available resources to use and then create whatever that can be produced by combining the limited available resources. In this sense, the theory argues that entrepreneurs will not just combine the resources to meet the desired goal, however, they are flexible with their goals by allowing the limited available resources to coach their strategic evolution. With this, they forgo the need for unavailable resources like capital or finance (Read \& Sarasvathy, 2005).

Relating the theory to this study, one can readily agree that the exposure of students to entrepreneurial education should teach them flexibility in achieving the set goals, by not solely being influenced by the financial accessibilities to determine their rigid decisions as observed in the verdicts of (Adeyele, 2018; Khan \& Anuar, 2018; Rupeika-Apoga, 2014)

\section{RESEARCH METHODOLOGY}

To achieve the objective of this study, quantitative methods of data collection were employed. This study uses an online survey to collect data from interested UUM participants. The link to the survey was shared via several students WhatsApp groups for one month. Within this period, a total respondent of 250 students chooses to participate in the study.

Items measurements used were adapted from earlier studies which were commonly used by several researchers. 8 items adapted from the studies of Autio, Keeley, Klofsten, Parker and Hay (2001), Lüthje and Franke (2003), and Linan and Chen (2009) were used in measuring entrepreneurial intention. Furthermore, entrepreneurial education items have 11 items. The items were adapted based on equipping students with needed entrepreneurial skills, cognition and opportunity recognition and resource dependency and resources exploration from the prior studies (Ozgen \& Baron, 2007; Souitaris, Zerbinati \& Al-Laham, 2007; Baum \& Locke, 2004; Keh, Der Foo \& Lim, 2002). Furthermore, items used in measuring access to finance was adapted from prior studies (Wiklund \& Shepherd, 2005; Chandler \& Hanks, 1998). A 5-point Likert scale was used based on its pros over other scales (Johns, 2010; Bertram, 2007). Also, in developing the items used in this study, a 5-point Likert scale was adopted. This is because of the advantages 5-point Likert scale has over other types of scales (Johns, 2010; Bertram, 2007).

\section{DATA ANALYSIS}

The data collected via the online questionnaire was analysed using statistical package for social sciences 'SPSS' version 23 with a pre-installed process macro by Hayes (2013). The analysis conducted includes missing values, outliers and normality observation using skewness and kurtosis approach. The reliability analysis and then linear regression with moderation effects using Hayes (2013) process macro.

\subsection{Normality}

The dependent variable was checked if by chance there is the presence of outliers which might cause the data not to assume normality. Normality is among the fundamental preliminary analysis needed to be performed before the parametric test is conducted.

Table 1. Normality

\begin{tabular}{llllll}
\hline & Mean & Median & SD & Skewness & Kurtosis \\
\hline El & 3.95 & 4.00 & .45 & .07 & -1.01 \\
\hline
\end{tabular}




\subsection{Reliability}

After confirming the data normality, the researchers proceed in examining the data reliability. According to the rule of thumb proposed by Zikmund, Babin, Carr, Griffin (2013), item with Cronbach's alpha of 0.6 and above is argued to have internal reliability. Checking the items used in measuring each variable, the Cronbach alpha was found to be above 0.6 that is, the entrepreneurial intention $(E I)=.951$, entrepreneurial education $(E E)=.777$ and access to finance $=.814$

\section{ANALYSIS REPORT AND DISCUSSION}

To fulfil the objective of this study, a regression analysis was conducted using SPSS version 23 with preinstalled process macro by Hayes (2013) relationship between the variables under investigation (entrepreneurial education and UUM students' entrepreneurial intention as well as the moderating effect of financial accessibility on the relationship between entrepreneurial education and entrepreneurial intention. The output is presented in Table 2.

\subsection{Regression Analysis with Moderating Effect}

The regression analysis present that the model examined is significant. In addition, the linear regression model present entrepreneurial education and access to finance explained $50.40 \%$ variance of UUM students' entrepreneurial intention having $r^{2}=.504$, $(F(3,246)=139.97, p<.05$. Furthermore, the regression result shows that UUM students who choose to participate in this survey perceive entrepreneurial education to significantly influence their intention to become entrepreneurs having $(\beta=.65, t=16.69), p<.05$.

Table 2. Linear Regression Analysis with the Moderating Effect of Access to Finance on the Relationship

\begin{tabular}{lllllll}
\multicolumn{7}{c}{ between Entrepreneurial Education and Entrepreneurial Intention } \\
\hline & Beta & SE & t-test & p-value & Decision & Direction \\
\hline EE & .65 & .04 & 16.69 & .00 & Significant & Positive \\
Finance & -.33 & .05 & -6.78 & .00 & Significant & Negative \\
EE*Fin $\rightarrow$ EI & .47 & .09 & 5.30 & .00 & & \\
$\mathbf{r}^{2}$ & .504 & & & & & \\
$\mathbf{r}$ & .710 & & & & & \\
\hline
\end{tabular}

The findings thus revealed that the samples of UUM students who agree to participate in this study have the notion that entrepreneurial education has a significant contribution to their intention to become entrepreneurs. The findings in this regard conform to the conclusions from earlier studies (Adelaja \& Arshad, 2016; Mbuya and Schachtebeck, 2016; Puni et al., 2018) where they conclude entrepreneurial education to be among the significant factors that its exposure enhances students' entrepreneurial intention. Besides, the regression model shows that the students perceive financial accessibility to be a significant factor that enhances their entrepreneurial intention having $(\beta=-.33, t=-6.78)$, $\mathrm{p}<.05$.

The implication is that the students perceived financial accessibility to have a significant influence on students' entrepreneurial intention. The observed result was consistent with the findings from the studies of (Adeyele, 2018; Khan \& Anuar, 2018; Rupeika-Apoga, 2014) explaining that they perceive ease of accessing finance motivates the students to explore the entrepreneurial opportunity. However, considering the negative sign presented by the regression result, it is therefore confirmed that the students 
perceived the availability of finance encourages the students towards entrepreneurship while they believe that no access to financial support means no entrepreneurial intention.

Therefore, observing the findings of the factors examined in this study, the observed result falls in line with the conclusions of earlier scholars (Adeyele, 2018; Khan \& Anuar, 2018; Rupeika-Apoga, 2014) perceiving access to finance as an important factor that influence and determined the intention of engaging in oneself in entrepreneurial activities. Also, the result confirmed the opinion expressed by previous studies (MäkimurtoKoivumaa, \& Puhakka, 2013; Read \& Sarasvathy, 2005) concluding that entrepreneurial education offered to students is more towards causation approach rather than effectuation. This is because the respondents perceived that the non-availability of financial access as perceived by the observed students implies decrease in their entrepreneurial intention.

Concerning the moderating effect of access to finance, the regression model shows that there is a significant moderating effect of access to finance on the relationship between entrepreneurial education and entrepreneurial intention having $(\beta=.47, t=5.30)$, $p<.05$. With the observed result, the authors conclude that the students surveyed believed that the perceived ease of access to finance plays a significant role in the implementation of the entrepreneurship knowledge, skills and entrepreneurial spirit gained via entrepreneurial education and their intention towards entrepreneurship. The result from this study was found to confirm the earlier findings of scholars such as (Adeyele, 2018; Khan \& Anuar, 2018; Sameen \& Cowling, 2015) where it was concluded that perceive ease of access to finance by nascent entrepreneurs positively enhance their entrepreneurial intention.

More so, the findings from this study confirmed the theory of effectuation used in this study as the empirical evidence shows that entrepreneurship intention formation should be treated as an effectual model and not a causal model. Could this be the missing link mentioned by Olorundare and Kayode (2014) concluding that entrepreneurial education is a significant factor, but there is a mismatch in what is being taught and what is needed in the society?

\subsection{Implication of Findings}

The findings reveal the practical significance of entrepreneurial education offered to samples at different stages. Although this study statistically proves entrepreneurial education to be an important factor that contributes to students' entrepreneurial intention, using effectuation theory, the practicality of entrepreneurial education offered is therefore questionable. With this, the authors of this study suggest entrepreneurial education revisitation. That is, the contents of entrepreneurial education offered to students to be designed in line with entrepreneurial thinking.

Despite the significant findings which can help in improving entrepreneurial education, the authors acknowledge some shortcomings of this study. These include the undefined sample frame, inclusion of limiting factors that influence entrepreneurial intention and perhaps, a biased literature review which might not cover some other noteworthy work done by earlier scholars. Given this and for more generalizability of result, the study advises future scholars to consider these shortcomings in their work.

\section{REFERENCES}

Adelaja, A. A., \& Arshad, D. (2016). Does Entrepreneurial Intention Differ Between Public and Private Universities' Students? International Journal of Entrepreneurship and Small \& Medium Enterprise. 3, 133 - 140. 
Adelaja, A. A., \& Minai, M. S. (2018). Students Entrepreneurial Intention Changes Due to entrepreneurial education exposure: The experimental design approach. Journal of Entrepreneurship Education, 21(4).

Adeyele, J. S. (2018). Financial institutions' criteria and mechanisms in financing small and medium enterprises in Plateau state, Nigeria. Ekonomski horizonti, 20(2), 109-125.

Ahmad, F. S., Baharun, R., \& Rahman, S. H. A. (2004). Interest in entrepreneurship: An exploratory study on engineering and technical students in entrepreneurship education and choosing entrepreneurship as a career. Project Report. Faculty of Management and Human Resource Development, Skudai, Johor. (Unpublished). Universiti Teknologi Malaysia Institutional Repository.[Online] Available: http://eprints. utm. my/2668.

Arasti, Z., Falavarjani, M. K., \& Imanipour, N. (2012). A Study of Teaching Methods in Entrepreneurship Education for Graduate Students. Higher Education Studies, 2(1), 2-10.

Autio, E., H. Keeley, R., Klofsten, M., GC Parker, G., \& Hay, M. (2001). Entrepreneurial intent among students in Scandinavia and in the USA. Enterprise and Innovation Management Studies, 2(2), 145-160.

Baruch, Y. (2009). To MBA or not to MBA. Career Development International, 14(4), 388-406.

Baum, J. R., \& Locke, E. A. (2004). The relationship of entrepreneurial traits, skill, and motivation to subsequent venture growth. Journal of applied psychology, 89(4), 587.

Bertram, D. (2007). Likert Scales... are the meaning of life: CPSC 681-Topic Report. Available from: Poincare. math. bg. ac. rs/ kristina//topic-dane-likert.

Bhaumik, S.K., Fraser, S. and Wright, M. (2015) What Do We Know About Entrepreneurial Finance and Its Relationship with Growth? International Small Business Journal. 33 (1). 70-88. ISSN $1741-2870$

Chandler, G. N., \& Hanks, S. H. (1998). An examination of the substitutability of founders human and financial capital in emerging business ventures. Journal of business venturing, 13(5), 353369.

Driga, O., Lafuente, E., \& Vaillant, Y. (2009). Reasons for the relatively lower entrepreneurial activity levels of rural women in Spain. Sociologia Ruralis, 49(1), 70-96.

Efrata, T., Hadiwidjojo, D., \& Aisjah, S. (2016). Entrepreneurship Education and Entrepreneurial Role Models: How do they affect Entrepreneurial Intentions? (Studies at Management and Business Students in Indonesia Universities).

Fowowe, B. (2017). Access to finance and firm performance: Evidence from African countries. Review of development finance, 7(1), 6-17.

Garba, A. S. (2010). Refocusing education system towards entrepreneurship development in Nigeria: a tool for poverty eradication. European Journal of social sciences, 15(1), 140-150.

Izedonmi, P. F. (2010). The Effect of Entrepreneurship Education on Students' Entrepreneurial Intentions. Global Journal of Management and Business Research, 10(6).

Johns, R. (2010). Likert items and scales. Survey Question Bank: Methods Fact Sheet, 1, 1-11.

Kayed, R. (2006). Islamic entrepreneurship: A case study of the Kingdom of Saudi Arabia. Unpublished PhD Thesis.

Keh, H. T., Der Foo, M., \& Lim, B. C. (2002). Opportunity evaluation under risky conditions: The cognitive processes of entrepreneurs. Entrepreneurship theory and practice, 27(2), 125-148.

Kerr, W., \& Nanda, R. (2009). Financing constraints and entrepreneurship (No. w15498). National Bureau of Economic Research.

Khan, S. J. M., \& Anuar, A. R. (2018). Access to Finance: Exploring Barriers to Entrepreneurship Development in SMEs. In Global Entrepreneurship and New Venture Creation in the Sharing Economy (pp. 92-111). IGI Global.

Kim, P. H., Aldrich, H. E., \& Keister, L. A. (2006). Access (not) denied: The impact of financial, human, and cultural capital on an entrepreneurial entry in the United States. Small business economics, 27(1), 5-22.

Kirby, D. A. (2004). Entrepreneurship education: can business schools meet the challenge?. Education+ training, 46(8/9), 510-519.

Kuratko, D. F. (2005). The emergence of entrepreneurship education: Development, trends, and challenges. Entrepreneurship theory and practice, 29(5), 577-597.

Lee, N., Sameen, H., \& Cowling, M. (2015). Access to finance for innovative SMEs since the financial crisis. Research Policy, 44(2), 370-380. 
Lee, N., Sameen, H., \& Cowling, M. (2015). Access to finance for innovative SMEs since the financial crisis. Research Policy, 44(2), 370-380.

Liñán, F., \& Chen, Y. W. (2009). Development and Cross-Cultural application of a specific instrument to measure entrepreneurial intentions. Entrepreneurship theory and practice, 33(3), 593-617.

Lüthje, C., \& Franke, N. (2003). The 'making' of an entrepreneur: testing a model of entrepreneurial intent among engineering students at MIT. R\&d Management, 33(2), 135-147.

Maina, S. (2014). The role of entrepreneurship education on job creation among youths in Nigeria. International Letters of Social and Humanistic Sciences, 4, 87-96.

Mäkimurto-Koivumaa, S., \& Puhakka, V. (2013). Effectuation and causation in entrepreneurship education. International Journal of Entrepreneurial Venturing, 5(1), 68-83.

Mbuya, J. M., \& Schachtebeck, C. (2016). Future entrepreneurs: Does the field of study matter? A comparison of students in a South African urban environment. Problems and Perspectives in Management, 14(2), 228-235.

Mc Namara, A., Murro, P., \& O'Donohoe, S. (2018). Credit Rationing in European SMEs and their Lending Infrastructure (No. 1803). Dipartimento di Economia e Finanza, LUISS Guido Carli.

Neck, H. M., \& Greene, P. G. (2011). Entrepreneurship education: known worlds and new frontiers. Journal of Small Business Management, 49(1), 55-70.

OECD (2012), Entrepreneurship at a Glance, chapter 2: "Measuring Entrepreneurial Finance: A European Survey of SMEs", OECD.

OECD (2013a), The Missing Entrepreneurs, Chapter 5: "Policies for Financing", OECD Publishing, Paris.

Olorundare, A. S., \& Kayode, D. J. (2014). Entrepreneurship education in Nigerian universities: A tool for national transformation. Asia Pacific Journal of Educators and Education, 29, 155-175.

Ozgen, E., \& Baron, R. A. (2007). Social sources of information in opportunity recognition: Effects of mentors, industry networks, and professional forums. Journal of business venturing, 22(2), 174-192.

Paul, K. I., \& Moser, K. (2009). Unemployment impairs mental health: Meta-analyses. Journal of Vocational Behaviour, 74(3), 264-282.

Praag, C. M. V., \& Ophem, H. V. (1995). Determinants of willingness and opportunity to start as an entrepreneur. Kyklos, 48(4), 513-540.

Puni, A., Anlesinya, A., \& Korsorku, P. D. A. (2018). Entrepreneurial education, self-efficacy and intentions in Sub-Saharan Africa. African Journal of Economic and Management Studies, 9(4), 492-511.

Read, S., \& Sarasvathy, S. D. (2005). Knowing what to do and doing what you know: Effectuation as a form of entrepreneurial expertise. The Journal of Private Equity, 45-62.

Rupeika-Apoga, R. (2014). Financing in SMEs: the case of the Baltic States. Procedia-Social and Behavioral Sciences, 150, 116-125.

Rupeika-Apoga, R. (2014). Financing in SMEs: the case of the Baltic States. Procedia-Social and Behavioral Sciences, 150, 116-125.

Souitaris, V., Zerbinati, S., \& Al-Laham, A. (2007). Do entrepreneurship programmes raise entrepreneurial intention of science and engineering students? The effect of learning, inspiration and resources. Journal of Business Venturing, 22(4), 566-591.

Wiebe, R. H. (1989). Businessmen and reform: A study of the progressive movement. Ivan R Dee. Wiklund, J., \& Shepherd, D. (2005). Entrepreneurial orientation and small business performance: A configurational approach. Journal of business venturing, 20(1), 71-91.

Zikmund, W. G. Babin, B. J., Carr, J. C., \& Griffin, M. (2013). Business research methods. Cengage Learning. 